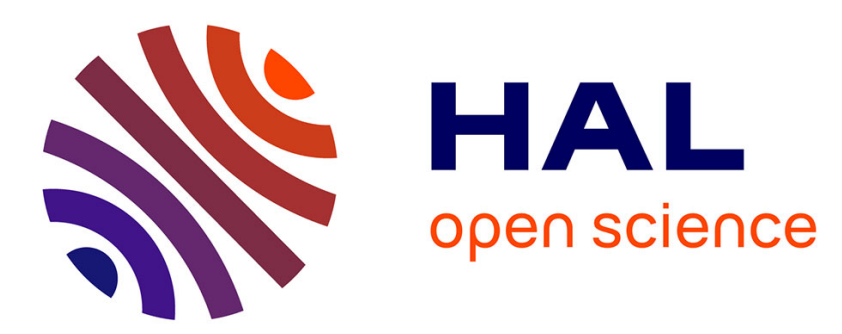

\title{
New unsaturated amino acids containing an allylsilane moiety on the lateral chain
}

Gianna Reginato, Alessandro Mordini, Patrick Meffre, Alice Tenti, Michela Valacchi, Kevin Cariou

\section{To cite this version:}

Gianna Reginato, Alessandro Mordini, Patrick Meffre, Alice Tenti, Michela Valacchi, et al.. New unsaturated amino acids containing an allylsilane moiety on the lateral chain. Tetrahedron: Asymmetry, 2006, 17 (6), pp.922-926. 10.1016/j.tetasy.2006.02.017 . hal-02002619

\section{HAL Id: hal-02002619 https://hal.science/hal-02002619}

Submitted on 11 Feb 2019

HAL is a multi-disciplinary open access archive for the deposit and dissemination of scientific research documents, whether they are published or not. The documents may come from teaching and research institutions in France or abroad, or from public or private research centers.
L'archive ouverte pluridisciplinaire HAL, est destinée au dépôt et à la diffusion de documents scientifiques de niveau recherche, publiés ou non, émanant des établissements d'enseignement et de recherche français ou étrangers, des laboratoires publics ou privés. 


\title{
New unsaturated amino acids containing an allylsilane moiety on the lateral chain
}

\author{
Gianna Reginato, ${ }^{\mathrm{a}, *}$ Alessandro Mordini, ${ }^{\mathrm{a}}$ Patrick Meffre, ${ }^{\mathrm{b}}$ Alice Tenti, ${ }^{\mathrm{a}}$ \\ Michela Valacchi ${ }^{\mathrm{a}, \dagger}$ and Kevin Cariou ${ }^{\mathrm{b}, \uparrow}$ \\ ${ }^{\text {a }}$ CNR ICCOM, Dipartimento di Chimica Organica 'U. Schiff', Università di Firenze, via della Lastruccia 13, \\ 50119 Sesto Fiorentino, Italy \\ $\mathrm{b}$ \\ Centre Universitaire de Formation et de Recherche de Nîmes, Site des Carmes, Place Gabriel Péri, 30000 Nîmes, France
}

\begin{abstract}
New enantiomerically enriched polyfunctionalized allylsilanes have been obtained from the synthetic elaboration of naturally occurring serine. In particular, an oxazolidine bearing an allylsilane framework on the lateral chain proved to be a suitable precursor for the corresponding silylated vinyl glycine derivatives.
\end{abstract}

\section{Introduction}

Amino acids have received great interest in the chiral pool of naturally occurring compounds. ${ }^{1}$ For several reasons, silylated ones are particularly attractive. They can be highly valuable optically active starting materials as the synthetic usefulness of amino acids is enhanced by the rich reactivity known for organosilanes. ${ }^{2}$ In addition, trialkylsilyl chains are known to have hydrophobic properties, which might be relevant for biological activity while some silylated amino acids have recently been developed in order to exploit new opportunities of silicon chemistry for drug design. ${ }^{3}$ For instance, $\beta$-trimethylsilylalanine has been successfully employed as a bio-isostere for phenylalanine in the search for stable renin inhibitors. ${ }^{4}$ More recently, silaproline has been found to lend unique properties to neurotensin analogues. ${ }^{5}$

Some examples of silylated amino acids have been reported in the literature so far, such as $\beta$-silylamino acids, ${ }^{6-8}$ $p$-substituted phenylananine, ${ }^{9}$ silaproline, ${ }^{10,11}$ and $a$-silyl

\footnotetext{
* Corresponding author. Tel.: +39 0554573558; fax: +39 0554573580; e-mail: gianna.reginato@unifi.it

${ }^{\dagger}$ Present address: Medicinal Chemistry 1, SienaBiotech S.p.A, via Fiorentina, 153100 Siena, Italy.

${ }^{\ddagger}$ Present address: Université Pierre et Marie Curie Paris VI, UMR 76114, Place Jussieu, 75252 Paris Cedex 05, France.
}

amino acids, which have been prepared both in racemic ${ }^{12,13}$ and in the enantiomerically enriched forms. ${ }^{14,15}$

Recently we have been able to prepare some enantiomerically enriched new silicon-containing amino acids starting from enantiomerically pure oxazolidine $\mathbf{1}$, a compound we synthesized for the first time some years ago, ${ }^{16-18}$ which can be obtained on multigram scales from naturally occurring serine. ${ }^{19}$ Oxazolidine $\mathbf{1}$ has been exploited as a helpful and versatile non-racemic building block to be used in the design and synthesis of non-natural $\alpha$-amino acids. ${ }^{20}$ In particular, silylcupration of compound 1 afforded intermediate vinyloxazolidine $\mathbf{2}$, which, after reduction of the double bond, removal of the acetonide protecting group and oxidation, led to silylated amino acids $\mathbf{3}$, bearing different trialkylsilyl substituents at the $\gamma$-position of the lateral chain $^{21}$ (Scheme 1).

Remarkably, the presence of a reactive double bond did not affect the yield of oxidation while unsaturated amino acid 4 could be recovered in satisfactory yield. This disclosed trialkylsilyl groups as suitable substituents for obtaining vinylglycine derivatives.

In view of these results we considered that the synthesis of novel silylated amino acids such as $\mathbf{5}$, bearing an allylsilyl moiety on the backbone (Scheme 2), could be also possible and of valuable synthetic interest, as allylsilanes have proven to be very versatile silicon-containing carbon 


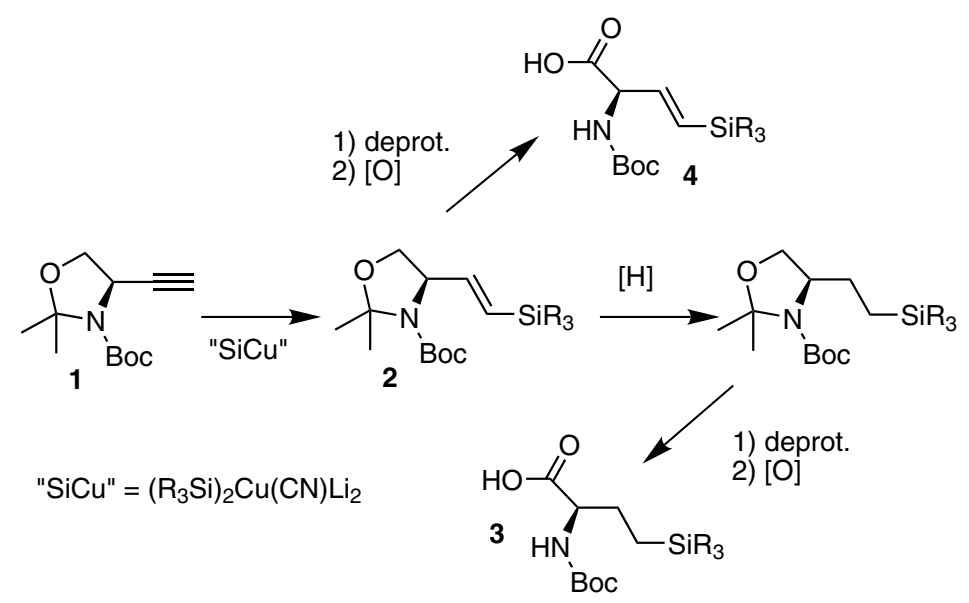

Scheme 1.
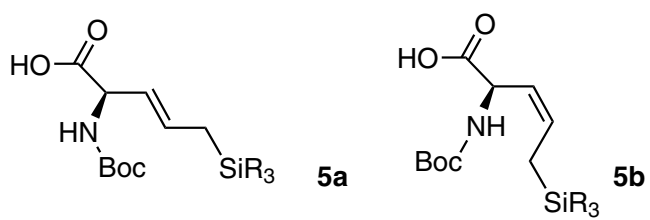

Scheme 2.

nucleophiles, often showing a high level of stereocontrol in reactions with electrophiles. ${ }^{2,22}$

The exploitation of these reagents in the synthesis of complex molecular structures is related to their availability as multifunctional enantiomerically enriched compounds. Although naturally occurring amino acids have been used, for instance, in the preparation of chiral amino silanes, ${ }^{23}$ to the best of our knowledge, enantiomerically enriched allylsilanes bearing an amino acid moiety have not been reported so far. Herein we report a convenient and stereoselective synthesis of $Z$ - and $E$-unsaturated siliconcontaining amino acids $\mathbf{5 a}$ and $\mathbf{5 b}$ using commercially available $\mathrm{L}$-serine as the starting material.

\section{Results and discussion}

Two different pathways have been considered for the synthesis of $E-\mathbf{5 a}$ and $Z-\mathbf{5 b}$ diastereoisomers. In both cases Garner's aldehyde 6, prepared from naturally occurring L-serine via standard methods, ${ }^{24}$ provided an attractive starting point.

Our approaches are described in Scheme 3. Vinyloxazolidines $9 \mathbf{a}$ and $\mathbf{b}$ were focused as key intermediate. Silylcuprates displacement of an allylic acetate is a well-established procedure for allylsilane synthesis. ${ }^{25}$ The reaction is antistereospecific and can be performed on acetate 7 to provide oxazolidine $9 \mathbf{a}$ as a direct precursor of the desired $E$-amino acid 5a. On the other hand syn-hydrogenation of alkyne $\mathbf{8}$, which can in turn be obtained from compound $\mathbf{1}$ through metalation and reaction with a suitable electrophile, was

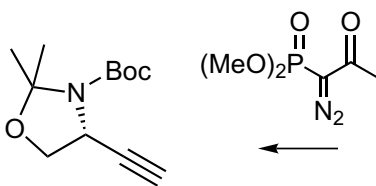<smiles>CC(C)(C)OC(=O)N1C(C=O)COC1(C)C</smiles>

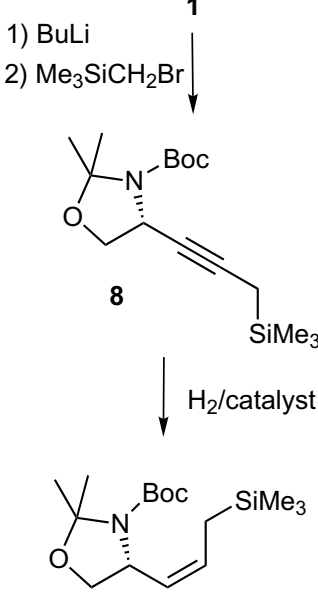

(Z)-9
6

1) $\mathrm{CIMg} \curvearrowright$<smiles>C=C[C@H](OC(C)=O)[C@H]1COC(C)(C)N1C(=O)OCc1ccccc1</smiles><smiles>CCCCC(C)(C)C(C)(C)C(C)(C)C</smiles>

$(E)-\mathbf{9}$
2) $\mathrm{CH}_{3} \mathrm{COCl}, \mathrm{Et}_{3} \mathrm{~N}$

Scheme 3.

envisaged as a simple way to obtain oxazolidine $\mathbf{9 b}$ and thus the opposite $Z$-isomer $\mathbf{5 b}$.

In agreement with what has already been reported, ${ }^{26,27}$ the addition of vinyl magnesium chloride onto Garner aldehyde 6 and esterification with acetylchloride gave anti-7 with a moderate selectivity (syn/ant $i=1 / 2.5$ ) and no racemization. As expected, trimethylsilylcyanocuprate reacted at low temperature with acetate 7 to afford, after hydrolytic work-up, allylsilanes 9 in a 95/5 mixture of $E$ - and $Z$-isomers, as determined by ${ }^{1} \mathrm{H}$ NMR analysis of the crude mixture. The desired isomer, 9a was finally obtained in $84 \%$ yield after chromatography. The double bond trans geometry was easily confirmed from the $15.2 \mathrm{~Hz}$ coupling constant we observed for the vinyl protons, which could be clearly measured by performing the ${ }^{1} \mathrm{H}$ NMR experiment 
at $50{ }^{\circ} \mathrm{C}$ in order to obtain the averaged spectrum of the slowly interconverting rotamers.

Alkylation of lithiated ethynyloxazolidine 1 with (bromomethyl)trimethylsilane gave the corresponding propargylsilane 8 in $57 \%$ yield, after purification. Lower yield were obtained when (chloromethyl)- or (iodomethyl)-trimethylsilanes were used. Catalytic hydrogenation of the corresponding alkynylsilanes is a widely used procedure for the preparation of $Z$-substituted allylsilanes. Hydrogenation is normally run in the presence of a palladium catalyst such as the Lindlar catalyst, ${ }^{28}$ or P-2 nickel (nickel boride). ${ }^{29}$ Reduction of our substrate $\mathbf{8}$ needed harsh conditions, but we were finally able to quantitatively obtain the desired $9 \mathrm{~b}$ by performing the hydrogenation at $50{ }^{\circ} \mathrm{C}$ in the presence of Lindlar catalyst and quinoline and under 50 bar of $\mathrm{H}_{2}$ pressure. Also in this case the double bond cis geometry was confirmed from the $10.8 \mathrm{~Hz}$ coupling constant we observed for the vinyl protons, in the ${ }^{1} \mathrm{H}$ NMR experiment, at $50^{\circ} \mathrm{C}$.

Finally opening of the oxazolidine ring and oxidation were performed using standard conditions. ${ }^{21}$ Treatment of each starting material with an excess of $\mathrm{CF}_{3} \mathrm{COOH}$ in $\mathrm{MeOH}$ at $0{ }^{\circ} \mathrm{C}$ gave essentially pure amino alcohols $\mathbf{1 0 a}$ and $\mathbf{b}$, which were used without further purification in the subsequent oxidative step. This was performed using periodic acid $\left(\mathrm{H}_{5} \mathrm{IO}_{6}\right)$ as the stoichiometric oxidant together with a catalytic amount of $\mathrm{CrO}_{3}$. Clean and high yielding oxidation occurred as shown in Scheme 4. For characterization purposes, crude protected amino acids were treated with excess MeI in the presence of $\mathrm{KHCO}_{3}$ and the corresponding methyl esters 11a and $\mathbf{b}$ were isolated in pure form after chromatography. Again we found that the presence of a reactive double bond in 10a and $\mathbf{b}$ did not affect the yield of oxidation while the corresponding amino esters, bearing an allylsilyl moiety on the lateral chain were recovered in satisfactory overall yield.

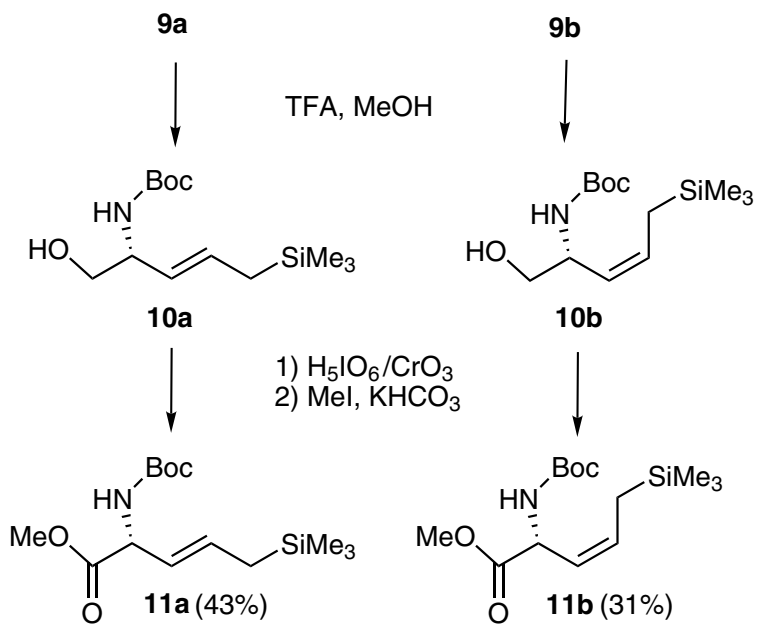

Scheme 4.

Crude amino acids 11a and $\mathbf{b}$ showed, however, sufficient purity for further uses. To confirm this, compound 11a was coupled with L-leucine methyl ester using EDC/HOBT coupling conditions to produce dipeptide 12, in 23\% overall yield after purification (Scheme 5).

${ }^{1} \mathrm{H}$ and ${ }^{13} \mathrm{C}$ NMR analysis of $\mathbf{1 2}$ indicated the absence (within limits of detection, i.e., $5 \%$ ) of peaks due to epimerization at the $\alpha$ carbon of the silylated amino acid. This confirmed that during our synthetic sequence no racemization of the starting material occurred and showed that our silylated amino acid was not affected by coupling conditions usually associated with peptides synthesis.

\section{Experimental}

\subsection{General methods and materials}

All reactions were carried out under a positive pressure of dry nitrogen. Ether extracts were dried over $\mathrm{Na}_{2} \mathrm{SO}_{4}$. Reactions were monitored by TLC on $\mathrm{SiO}_{2}$; detection was made using a $\mathrm{KMnO}_{4}$ basic solution. Flash column chromatography $^{30}$ was performed using glass columns $(10-50 \mathrm{~mm}$ wide) and $\mathrm{SiO}_{2}$ 230-400 mesh. ${ }^{1} \mathrm{H}$ NMR spectra were recorded at 200 or $400 \mathrm{MHz} .{ }^{13} \mathrm{C}$ NMR spectra were recorded at $50.3 \mathrm{MHz}$. Chemical shifts were determined relative to the residual solvent peak $\left(\mathrm{CHCl}_{3} \delta 7.26\right.$ for ${ }^{1} \mathrm{H}$ NMR; $\mathrm{CHCl}_{3} \delta 77.0$ for ${ }^{13} \mathrm{C}$ NMR). For those compounds, which are present as slowly interconverting rotamers, ${ }^{1} \mathrm{H}$ NMR experiments were performed at $50^{\circ} \mathrm{C}\left(\mathrm{CDCl}_{3}\right)$ and the signals of the averaged spectrum reported when possible. Coupling constants $(J)$ are reported in Hertz. When necessary, $J$ values were obtained through selective decoupling. Multiplicities are indicated as s (singlet), $\mathrm{d}$ (doublet), $\mathrm{t}$ (triplet), q (quartet), $\mathrm{m}$ (multiplet), and br s (broad singlet). Mass spectra were obtained at a $70 \mathrm{eV}$ ionization potential and are reported in the form $\mathrm{m} / \mathrm{z}$ (intensity relative to base $=100$ ). Polarimetric measurements were performed in $\mathrm{CHCl}_{3}$ solution at $\lambda=589 \mathrm{~nm}$, while the temperature is specified case by case.

Starting materials $\mathbf{1}$ and $\mathbf{7}$ were prepared according to the literature. ${ }^{18,26}$ THF was dried by distillation over sodium benzophenone ketyl. Petroleum ether, unless specified, is the $40-70{ }^{\circ} \mathrm{C}$ boiling fraction.

\section{2. (4R)-2,2-Dimethyl-4-( $E$-3-trimethylsilanyl-propenyl)- oxazolidine-3-carboxylic acid tert-butyl ester 9a}

Trimethylsilylcyanocuprate was prepared according to the general route, ${ }^{21}$ using hexamethyldisilane $(0.307 \mathrm{~mL}$, $1.5 \mathrm{mmol}), \mathrm{MeLi}(1.6 \mathrm{M}$ solution in THF, $0.46 \mathrm{~mL}$, $0.74 \mathrm{mmol}$ ), and $\mathrm{CuCN}$ (33 mg, $0.37 \mathrm{mmol}$ ). Oxazolidine 7 (syn/anti $=1 / 2.5,100 \mathrm{mg}, 0.33 \mathrm{mmol})$ was dissolved in THF $(0.6 \mathrm{~mL})$ added at $-23^{\circ} \mathrm{C}$ and left at this temperature for $30 \mathrm{~min}$. The reaction mixture was hydrolyzed with $\mathrm{NH}_{4} \mathrm{Cl} / \mathrm{NH}_{4} \mathrm{OH}$ buffer solution, extracted with $\mathrm{Et}_{2} \mathrm{O}$, then washed with brine, and dried over $\mathrm{Na}_{2} \mathrm{SO}_{4}$. After solvent evaporation and purification (petroleum ether/ethyl acetate $=10 / 1) 88 \mathrm{mg}$ of $\mathbf{9 a}$ were recovered as a colorless oil (yield: $84 \%) .{ }^{1} \mathrm{H}$ NMR $\left(400 \mathrm{MHz}, 50{ }^{\circ} \mathrm{C}\right) \delta: 5.65-5.56[\mathrm{~m}$, $1 \mathrm{H}] ; \quad 5.32-5.26\left[\mathrm{dd}, \quad J_{\text {trans }}=15.2 \mathrm{~Hz}, J=7.6 \mathrm{~Hz}, 1 \mathrm{H}\right]$; $4.33-4.22[\mathrm{~m}, 1 \mathrm{H}] ; 4.01-3.97\left[\mathrm{~m}, J_{\mathrm{AB}}=8.8 \mathrm{~Hz}, J_{\mathrm{BX}}=\right.$ $6.0 \mathrm{~Hz}, 1 \mathrm{H}] ; 3.70-3.67\left[\mathrm{~m}, J_{\mathrm{AB}}=8.8 \mathrm{~Hz}, J_{\mathrm{AX}}=2.2 \mathrm{~Hz}\right.$, 


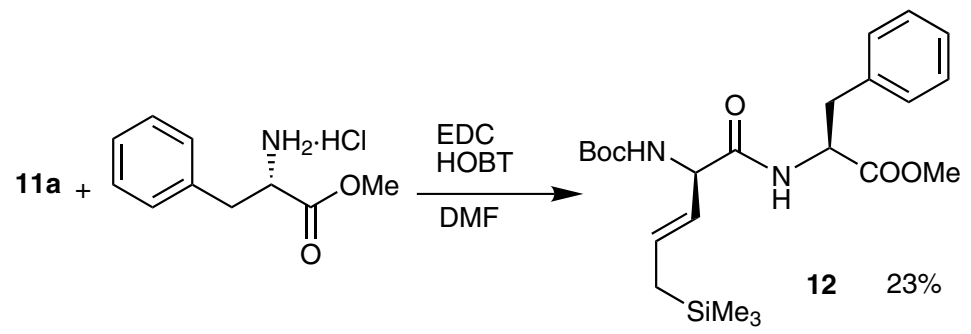

Scheme 5.

$1 \mathrm{H}] ; 1.58[\mathrm{~s}, 3 \mathrm{H}] ; 1.50[\mathrm{~s}, 3 \mathrm{H}] ; 1.49-1.45[\mathrm{br} \mathrm{m}, 2 \mathrm{H}+9 \mathrm{H}]$; 0.01 [s, 9H]. ${ }^{13} \mathrm{C}$ NMR $(50.3 \mathrm{MHz}) \delta$ : 152.0; 128.6; 126.1; $93.8 ; 79.9 ; 68.7 ; 59.3 ; 28.5 ; 27.7 ; 24.0 ; 22.6 ;-1.9$. MS $m / e: 257(4) ; 57(100) ; 73(54) .[\alpha]_{\mathrm{D}}^{26}=-22.0\left(c 1.31, \mathrm{CHCl}_{3}\right)$. Anal. Calcd for $\mathrm{C}_{16} \mathrm{H}_{31} \mathrm{NO}_{3} \mathrm{Si}$ : C, 61.30; H, 9.97; N, 4.47. Found: C, 61.42; H, 9.93; N, 4.51.

\subsection{Synthesis of (4R)-2,2-dimethyl-4-(3-trimethylsilanyl- prop-1-ynyl)-oxazolidine-3-carboxylic acid tert-butyl ester 8}

Oxazolidine 1 (175 mg, $1.0 \mathrm{mmol})$ was dissolved in THF $(4 \mathrm{~mL})$ and after cooling at $-78^{\circ} \mathrm{C}$ reacted with $\mathrm{BuLi}$ $(1.6 \mathrm{M}, 0.48 \mathrm{~mL}, 1 \mathrm{mmol})$. The mixture was stirred at $-78{ }^{\circ} \mathrm{C}$ for $60 \mathrm{~min}$, then after the temperature had risen to $-23{ }^{\circ} \mathrm{C}$, left to react for further $30 \mathrm{~min}$. $\mathrm{Me}_{3} \mathrm{SiCH}_{2} \mathrm{Br}$ $(158 \mathrm{mg}, 1.2 \mathrm{mmol})$ was then added, and after rising to room temperature, left to react for $18 \mathrm{~h}$. The reaction mixture was hydrolized with water, extracted with $\mathrm{Et}_{2} \mathrm{O}$, then washed with brine, and dried over $\mathrm{Na}_{2} \mathrm{SO}_{4}$. After solvent evaporation and purification (petroleum ether/ethyl acetate $=7 / 1), 178 \mathrm{mg}$ of $\mathbf{8}$ were recovered as a colorless oil (yield: $57 \%$ ). ${ }^{1} \mathrm{H}$ NMR $\left(400 \mathrm{MHz}, 50{ }^{\circ} \mathrm{C}\right) \delta: 4.58-4.42[\mathrm{~m}$, $1 \mathrm{H}] ; 3.96-3.92 \quad\left[\mathrm{~m}, J_{\mathrm{AB}}=8.4 \mathrm{~Hz}, J_{\mathrm{AX}}=6.2 \mathrm{~Hz}, 1 \mathrm{H}\right]$; $3.87-3.84\left[\mathrm{~m}, J_{\mathrm{AB}}=8.4 \mathrm{~Hz}, J_{\mathrm{BX}}=1.2 \mathrm{~Hz}, 1 \mathrm{H}\right] ; 1.57[\mathrm{br} \mathrm{s}$, $6 \mathrm{H}] ; 1.44-1.40[\mathrm{br} \mathrm{m}, 9 \mathrm{H}+2 \mathrm{H}] ; 0.05[\mathrm{~s}, 9 \mathrm{H}] .{ }^{13} \mathrm{C} \mathrm{NMR}$ $(50.3 \mathrm{MHz}) \quad \delta$ : 151.4; 93.9; 93.4; 79.8; 77.9; 69.5; 48.8; $28.3 ; 25.2 ; 24.2 ; 6.8 ;-2.2$. MS m/e: 255 (3); 57 (100); 73 (34). $[\alpha]_{\mathrm{D}}^{24}=-108.5$ (c 1.38, $\mathrm{CHCl}_{3}$ ). Anal. Calcd for $\mathrm{C}_{16} \mathrm{H}_{29} \mathrm{NO}_{3} \mathrm{Si}: \mathrm{C}, 61.69 ; \mathrm{H}, 9.38 ; \mathrm{N}, 4.50$. Found: $\mathrm{C}$, 61.65; H, 9.59; N, 4.47 .

\section{4. (4R)-2,2-Dimethyl-4-[(Z)-3-trimethylsilanyl-prop-1- enyl-oxazolidine-3-carboxylic acid tert-butyl ester $9 \mathrm{~b}$}

Alkyne 8 (121 mg, $0.39 \mathrm{mmol})$ was dissolved in ethyl acetate $(4 \mathrm{~mL})$ together with the catalyst $\left(\mathrm{Pd} / \mathrm{BaSO}_{4}, 4 \mathrm{mg}\right.$, $10 \%)$ and $2-3$ drops of quinoline. The solution was reacted under $\mathrm{H}_{2}(50 \mathrm{~atm})$ at $50{ }^{\circ} \mathrm{C}$ for $20 \mathrm{~h}$ then filtered over Celite and evaporated. Purification (petroleum ether/ethyl acetate $=20 / 1$ ) afforded $109 \mathrm{mg} \mathbf{9 b}$ as a colorless oil (yield: $90 \%) .{ }^{1} \mathrm{H}$ NMR $\left(400 \mathrm{MHz}, 50{ }^{\circ} \mathrm{C}\right) \delta: 5.54-5.47[\mathrm{~m}, 1 \mathrm{H}]$; $5.36-5.30\left[\mathrm{dd}, J_{\text {cis }}=10.8 \mathrm{~Hz}, J=9.9 \mathrm{~Hz}, 1 \mathrm{H}\right] ; 4.64-4.56$ $[\mathrm{m}, 1 \mathrm{H}] ; 4.07-4.02\left[\mathrm{~m}, J_{\mathrm{AB}}=8.4 \mathrm{~Hz}, J_{\mathrm{BX}}=6.4 \mathrm{~Hz}, 1 \mathrm{H}\right]$; $3.66-3.62\left[\mathrm{~m}, J_{\mathrm{AB}}=8.4 \mathrm{~Hz}, J_{\mathrm{AX}}=3.0 \mathrm{~Hz}, 1 \mathrm{H}\right] ; 1.59[\mathrm{~s}$, $3 \mathrm{H}] ; 1.52[\mathrm{~s}, 3 \mathrm{H}] ; 1.49-1.45$ [br m, 9H + 2H]; $0.01[\mathrm{~s}, 9 \mathrm{H}]$. ${ }^{13} \mathrm{C}$ NMR $(50.3 \mathrm{MHz}) \delta$ : 151.9; 126.9 (2C), 97.4; 79.6; $68.9 ; 54.1 ; 28.5 ; 26.7 ; 24.5 ; 18.9 ;-1.7 . \mathrm{MS} m / e$ : 257 (6); 57 (100); 73 (53). $[\alpha]_{\mathrm{D}}^{25}=-152.3$ (c 0.7, $\left.\mathrm{CHCl}_{3}\right)$. Anal. Calcd for $\mathrm{C}_{16} \mathrm{H}_{31} \mathrm{NO}_{3} \mathrm{Si}$ : C, 61.30; H, 9.97; N, 4.47. Found: C, 61.46; H, 10.01; N, 4.45.

\subsection{Deprotection to amino alcohols}

A solution of oxazolidine 9 in $\mathrm{MeOH}$ was cooled to $32{ }^{\circ} \mathrm{C}$ and then treated with an excess of $\mathrm{CF}_{3} \mathrm{COOH}$. After completion, volatile components were evaporated under reduced pressure and the residue was redissolved in ethyl acetate. The organic layer was washed with saturated $\mathrm{NaHCO}_{3}$ aqueous solution and brine, then dried over $\mathrm{Na}_{2} \mathrm{SO}_{4}$ and evaporated to afford pure amino alcohols 10a,b, which were oxidized without further purification.

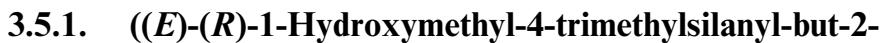
enyl)-carbamic acid tert-butyl ester 10a. Oxazolidine 9a (168 $\mathrm{mg}, 0.54 \mathrm{mmol}$ ) was deprotected to afford crude 10a (146 mg, quantitative). ${ }^{1} \mathrm{H}$ NMR (200 MHz) $\delta: 5.72-5.54$ $[\mathrm{m}, 1 \mathrm{H}] ; 5.21-5.10\left[\mathrm{dd}, J_{\text {trans }}=15.4 \mathrm{~Hz}, J=6.6 \mathrm{~Hz}, 1 \mathrm{H}\right]$; $4.18-4.02[\mathrm{~m}, 1 \mathrm{H}] ; 3.70-3.45[\mathrm{~m}, 2 \mathrm{H}] ; 1.50-1.41[\mathrm{br} \mathrm{m}$, $9 \mathrm{H}+2 \mathrm{H}] ;-0.03[\mathrm{~s}, 9 \mathrm{H}] .{ }^{13} \mathrm{C}$ NMR $(50.3 \mathrm{MHz}) \delta: 156.0$; $129.9 ; 124.8 ; 79.6 ; 65.8 ; 54.9 ; 28.4 ; 22.9 ;-1.9$.

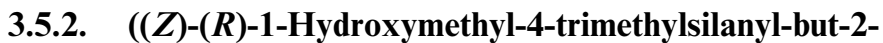
enyl)-carbamic acid tert-butyl ester 10b. Oxazolidine 9b (47 mg, $0.15 \mathrm{mmol}$ ) was deprotected to afford crude 10b (40 mg, quantitative). ${ }^{1} \mathrm{H}$ NMR (200 MHz) $\delta: 5.71-5.55$ $[\mathrm{m}, 1 \mathrm{H}] ; 5.19-5.09$ [dd, $\left.J_{\text {cis }}=10.6 \mathrm{~Hz}, J=8.8 \mathrm{~Hz}, 1 \mathrm{H}\right]$; 4.60-4.48 [m, 1H]; 3.75-3.55 [m, 2H]; $1.57[\mathrm{~d}, 2 \mathrm{H}$, $J=8.8 \mathrm{~Hz}] ; 1.45[\mathrm{~s}, 9 \mathrm{H}] ;-0.02[\mathrm{~s}, 9 \mathrm{H}] .{ }^{13} \mathrm{C}$ NMR $(50.3 \mathrm{MHz}) \delta$ : $156.3 ; 132.6 ; 121.0 ; 79.9 ; 64.5 ; 50.7 ; 28.4$; $19.6 ;-1.8$.

\subsection{Oxidation of amino alcohols}

To a solution of amino alcohol in wet acetonitrile, cooled to $0{ }^{\circ} \mathrm{C}$, were added $\mathrm{H}_{5} \mathrm{IO}_{6}$ (2.6 equiv) and $\mathrm{CrO}_{3}(2 \%)$. After $30 \mathrm{~min}$, the mixture was diluted with ethyl acetate and the organic layer washed with water, brine and dried over $\mathrm{Na}_{2} \mathrm{SO}_{4}$. After evaporation of the solvent, crude amino acid was redissolved in dry DMF, then $\mathrm{NaHCO}_{3}$ ( 2 equiv) and MeI ( 2 equiv) were added at room temperature. The mixture was left to react for $18 \mathrm{~h}$, then ethyl acetate was added and the organic layer washed with saturated $\mathrm{NH}_{4} \mathrm{Cl}$ aqueous solution, brine and dried over $\mathrm{Na}_{2} \mathrm{SO}_{4}$. Evaporation afforded crude amino ester, which was purified by flash chromatography.

3.6.1. (2R)-2-tert-Butoxycarbonylamino-5-trimethylsilanyl$\boldsymbol{E}$-pent-3-enoic acid methyl ester 11a. Amino alcohol 10a (73 $\mathrm{mg}, 0.26 \mathrm{mmol}$ ) was oxidized to the corresponding amino acid (68 mg, 88\% yield) and converted to amino ester. 
Purification ( $n$-pentane/ethyl acetate $=15 / 1)$ afforded 11a (34 mg, 43\% overall yield) as a colorless oil. : ${ }^{1} \mathrm{H}$ NMR $(400 \mathrm{MHz}) \delta: 5.82-5.72\left[\mathrm{~m}, 1 \mathrm{H}, J_{\text {trans }}=15.2 \mathrm{~Hz}\right] ; 5.27-$ $5.21\left[\mathrm{dd}, 1 \mathrm{H}, J_{\text {trans }}=15.2 \mathrm{~Hz}, J=7.2 \mathrm{~Hz}\right] ; 5.14-5.10[\mathrm{~m}$, $1 \mathrm{H}] ; 3.73[\mathrm{~s}, 3 \mathrm{H}] ; 1.49[\mathrm{~d}, 2 \mathrm{H}, J=9.6 \mathrm{~Hz}] ; 1.43[\mathrm{~s}, 9 \mathrm{H}]$; $-0.01[\mathrm{~s}, 9 \mathrm{H}] .{ }^{13} \mathrm{C}$ NMR $(50.3 \mathrm{MHz}) \delta: 172.1 ; 154.7$; $132.3 ; 122.2 ; 79.8 ; 55.7 ; 52.3 ; 28.3 ; 23.0 ;-1.9$. MS m/e: 245 (7); 213 (5); 186 (17); 142 (28); 112 (43); 73 (100); 57 (83). $[\alpha]_{\mathrm{D}}^{24}=-125.4\left(c \quad 0.69, \mathrm{CHCl}_{3}\right)$. Anal. Calcd for $\mathrm{C}_{14} \mathrm{H}_{27} \mathrm{NO}_{4} \mathrm{Si}: \mathrm{C}, 55.78 ; \mathrm{H}, 9.03$; N, 4.65. Found: $\mathrm{C}$, $55.87 ; \mathrm{H}, 10.04, \mathrm{~N}, 4.63$.

3.6.2. (2R)-2-tert-Butoxycarbonylamino-5-trimethylsilanyl$Z$-pent-3-enoic acid methyl ester 11b. Amino alcohol 10b (47 mg, $0.15 \mathrm{mmol}$ ) was oxidized to the corresponding amino acid (41 mg, 95\% yield) and converted to amino ester. Purification ( $n$-pentane/ethyl acetate $=15 / 1)$ afforded 11b (16 mg, 31\% overall yield) as a colorless oil. ${ }^{1} \mathrm{H}$ NMR $(400 \mathrm{MHz}) \delta: 5.76-5.69\left[\mathrm{~m}, 1 \mathrm{H}, J_{\text {cis }}=10.4 \mathrm{~Hz}\right] ; 5.19-5.14$ $\left[\mathrm{dd}, 1 \mathrm{H}, J_{\text {cis }}=10.4 \mathrm{~Hz}, J=9.2 \mathrm{~Hz}\right] ; 5.02-4.91[\mathrm{~m}, 1 \mathrm{H}] ;$ $3.72[\mathrm{~s}, 3 \mathrm{H}] ; 1.51-1.43[\mathrm{br} \mathrm{m}, 2 \mathrm{H}+9 \mathrm{H}] ; 0.03[\mathrm{~s}, 9 \mathrm{H}] .{ }^{13} \mathrm{C}$ NMR $(50.3 \mathrm{MHz}) \delta$ : $172.6 ; 154.9 ; 133.4 ; 120.7 ; 79.2 ; 52.3$; 51.1; 28.3; 19.5; -1.8. MS m/e: 245 (8); 242 (4); 228 (2); $186 \quad(21) ; 142 \quad$ (27); 112 (49); $73 \quad$ (100); $57 \quad$ (94). $[\alpha]_{\mathrm{D}}^{24}=-81.2\left(\right.$ c $\left.0.52, \mathrm{CHCl}_{3}\right)$. Anal. Calcd for $\mathrm{C}_{14} \mathrm{H}_{27} \mathrm{NO}_{4}-$ Si: C, 55.78; H, 9.03; N, 4.65. Found: C, 55.90; H, 9.09; $\mathrm{N}, 4.72$.

\section{7. $\left(2 S, 2^{\prime} R\right)-2-\left(2^{\prime}-\right.$ tert-Butoxycarbonylamino-5-tri- methylsilanyl- $E$-pent-3-enoylamino)-3-phenyl-propionic acid methyl ester 12}

To a solution of crude amino acid derivative 11a $(81 \mathrm{mg}$, $0.28 \mathrm{mmol})$ in dry DMF $(0.7 \mathrm{~mL})$, L-phenylalanine methyl ester hydrochloride $(61 \mathrm{mg}, 0.28 \mathrm{mmol})$, and DIPEA (40 mg, $0.31 \mathrm{mmol}$ ) were added and then cooled to $0{ }^{\circ} \mathrm{C}$. EDC (60 mg, $0.31 \mathrm{mmol})$ and HOBt $(11 \mathrm{mg}, 0.08 \mathrm{mmol})$ were added and the mixture was allowed to react at room temperature for 3 days, then the solvent was evaporated and the residue redissolved in ethyl acetate. The organic layer was washed with water, $\mathrm{HCl} 0.1 \mathrm{M}, \mathrm{NaOH} 0.1 \mathrm{M}$, brine and dried over $\mathrm{Na}_{2} \mathrm{SO}_{4}$. Purification (petroleum ether/ethyl acetate $=5 / 1$ ) afforded $29 \mathrm{mg}$ of $\mathbf{1 2}$ as a colorless oil (yield: $23 \%) .{ }^{1} \mathrm{H}$ NMR $(400 \mathrm{MHz}) \delta: 7.31-7.06$ $[\mathrm{m}, 5 \mathrm{H}] ; 6.38-6.27[\mathrm{~m}, 1 \mathrm{H}] ; 5.81-5.70[\mathrm{~m}, 1 \mathrm{H}] ; 5.19-5.14$ $\left[\mathrm{dd}, J_{\text {trans }}=15.0 \mathrm{~Hz}, J=7.8 \mathrm{~Hz}, 1 \mathrm{H}\right] ; 4.88-4.81[\mathrm{~m}, 1 \mathrm{H}]$; $4.58-4.45[\mathrm{~m}, 1 \mathrm{H}] ; 3.70[\mathrm{~s}, 3 \mathrm{H}] ; 3.18-3.02[\mathrm{~m}, 2 \mathrm{H}] ; 1.51-$ 1.39 [br m, 2H + 9H]; $-0.01 \quad[\mathrm{~s}, \quad 9 \mathrm{H}] ;{ }^{13} \mathrm{C}$ NMR (50.3 MHz) $\delta$ : $171.5 ; 170.1 ; 154.8 ; 135.5 ; 133.1 ; 129.2$; $128.4 ; 127.1 ; 123.6 ; 79.7 ; 57.0 ; 53.2 ; 52.3 ; 37.9 ; 28.3 ; 23.1$; -1.9. MS m/e: 200 (3); 156 (2); 144 (3); 114 (3); 100 (11); $83(4) ; 57(100) .[\alpha]_{\mathrm{D}}^{25}=-11.2\left(c 0.69, \mathrm{CHCl}_{3}\right)$. Anal. Calcd for $\mathrm{C}_{23} \mathrm{H}_{36} \mathrm{~N}_{2} \mathrm{O}_{5} \mathrm{Si}$ : C, 61.58; H, 8.09; N, 6.24. Found: C, 61.66; H, 8.12; N, 6.18.

\section{References}

1. Coppola, G. M.; Schuster, H. F. Asymmetric Synthesis: Construction of Chiral Molecules Using Amino Acids; John Wiley \& Sons: New York, 1987.

2. Fleming, I.; Barbero, A.; Walter, D. Chem. Rev. 1997, 97, 2063.

3. Bains, W.; Tacke, R. Curr. Opin. Drug Disc. Dev. 2003, 6, 526 , and references cited therein.

4. Weidman, B. Chimia 1992, 46, 312.

5. Cavelier, F.; Vivet, B.; Martinez, J.; Aubry, A.; Didierjean, C.; Vicherat, A.; Marraud, M. J. Am. Chem. Soc. 2002, 124, 2917.

6. Merget, M.; Gunther, K.; Bernd, M.; Gunther, E.; Tacke, R. J. Organomet. Chem. 2001, 628, 183.

7. Tacke, R.; Schmid, T.; Merget, M. Organometallics 2005, 24, 1780.

8. Kenworthy, M. N.; Kilburn, J. P.; Taylor, R. J. K. Org. Lett. 2004, 6, 19.

9. Frankel, M.; Shenhar, A.; Gertner, D.; Zilkha, A. Israel J. Chem. 1968, 6, 921.

10. Handmann, V. I.; Merget, M.; Tacke, R. Z. Naturfursch. 2000, 55B, 133 .

11. Vivet, B.; Cavelier, F.; Martinez, J. Eur. J. Org. Chem. 2000 , 807.

12. Sieburth, S. M.; Somers, J. J.; O’Hare, H. K.; Hewitt, G. W. Appl. Organomet. Chem. 1997, 11, 337.

13. Bolm, C.; Kasyan, A.; Drauz, K.; Gunther, K.; Raabe, G. Angew. Chem., Int. Ed. 2000, 39, 2288.

14. Chen, J.-X.; Tunge, J. A.; Norton, J. R. J. Org. Chem. 2002, $67,4366$.

15. Liu, G.; Sieburth, S. M. Org. Lett. 2003, 5, 4677.

16. Meffre, P.; Gauzy, L.; Perdigues, C.; Desanges-Leveque, F.; Branquet, E.; Durand, P.; Le Goffic, F. Tetrahedron Lett. 1995, 36, 877.

17. Meffre, P.; Gauzy, L.; Branquet, E.; Durand, P.; Goffic, F. L. Tetrahedron 1996, 52, 11215.

18. Reginato, G.; Mordini, A.; Degl'Innocenti, A.; Caracciolo, M. Tetrahedron Lett. 1995, 36, 8275.

19. Meffre, P.; Hermann, S.; Durand, P.; Reginato, G.; Riu, A. Tetrahedron 2002, 58, 5159.

20. Reginato, G.; Meffre, P.; Gaggini, F. Amino Acids 2005, 29 , 81.

21. Reginato, G.; Mordini, A.; Valacchi, M.; Grandini, E. J. Org. Chem. 1999, 64, 9545.

22. Chabaud, L.; James, P.; Landais, Y. Eur. J. Org. Chem. 2004, 3173.

23. Franciotti, M.; Mann, A.; Mordini, A.; Taddei, M. Tetrahedron Lett. 1993, 34, 1355.

24. Garner, P.; Park, J. M. Org. Synth. 1992, 70, 18.

25. Fleming, I.; Higgins, D.; Lawrence, N. J.; Thomas, A. P. J. Chem. Soc., Perkin Trans. 1 1992, 24, 3331.

26. Ibuka, T.; Habashita, H.; Otaka, A.; Fuji, N.; Oguchi, Y.; Uyehara, T.; Yamamoto, Y. J. Org. Chem. 1991, 56, 4370.

27. Coleman, R. S.; Carpenter, A. J. Tetrahedron Lett. 1992, 33 , 1697.

28. Mohr, P. Tetrahedro Lett. 1995, 36, 2453.

29. Tietze, L. F.; Thede, K.; Schimpf, R.; Sannicolò, F. Chem. Commun. 2000, 583.

30. Still, W. C.; Kahn, M. K.; Mitra, A. J. Org. Chem. 1978, 43, 293. 